\title{
INFERRING TRANSPIRATION CONTROL FROM SAP FLOW HEAT GAUGES AND THE PENMAN-MONTEITH EQUATION
}

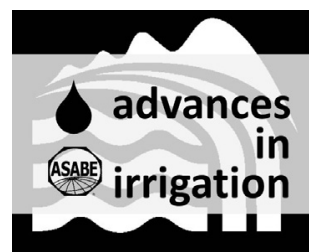

\author{
R. M. Aiken, N. L. Klocke
}

\begin{abstract}
In situ measurements of crop transpiration can enhance field studies of crop water use and productivity. Our objectives were to develop and evaluate a canopy resistance model, to evaluate operational characteristics of sap flow heat gauges (SFHG) for field corn (Zea mays L.), and to compare transpiration flux calculated by SFHG with evapotranspiration (ET) calculated by a Penman-Monteith (P-M) algorithm. Five sap flow heat gauges, controlled by an automated data acquisition system, were deployed in each of four replicated field plots of corn irrigated to limit water deficits to $50 \%$ of available water capacity at Garden City, Kansas, in 2004 and 2006. Water flux through each stem was estimated as a residual of a heat balance equation. Gauges were transferred to adjacent plants after 13 to 21 days to evaluate and mitigate functional stem damage. Loss of gauge operation, primarily due to stem damage, commonly occurred approximately one to two weeks following installation. Data screened using operational metrics were used to evaluate a scaling relationship between calculated flow to ET calculated following the P-M form. A canopy resistance model was derived from principles of radiation use. Transpiration calculated from gauge data was linearly related to ET calculated from the P-M, with $R^{2}$ exceeding 0.79. Greater precision was obtained by assuming constant canopy resistance $\left(r_{c}\right)$, but predictive bias was reduced by assuming that $r_{c}$ was proportional to solar radiation. Sap flow ganges provided information useful for calibrating an $r_{c}$ model for P-M to calculate the transpiration component of ET; the model linking canopy resistance to absorbed radiation has application to dual-source and thermal-based energy balance models of crop ET.
\end{abstract}

Keywords. Canopy resistance, Evaporation, Penman-Monteith, Radiation use, Sap flow heat gauges, Transpiration.

$\mathrm{T}$ ranspiration can be considered as the productive component of evapotranspiration (ET) from an agricultural perspective. Partitioning ET into evaporation (E) and transpiration (T) components permits evaluation of water management with regard to crop productivity and water conservation. Lascano et al (1994) showed that crop residue management, which shifted water use from $\mathrm{E}$ to $\mathrm{T}$, resulted in a corresponding increase in cotton (Gossypium hirsutum L.) lint yield. However, quantifying the separate $\mathrm{E}$ and $\mathrm{T}$ components of $\mathrm{ET}$ is confounded by (1) crop canopy effects on convective and radiative exchanges within the canopy sub-layer, (2) nearsurface root water extraction, and (3) measurement methods that integrate the effects of both $\mathrm{E}$ and $\mathrm{T}$ processes (e.g., soil water balance, micrometeorology, lysimetry). Direct knowledge of factors controlling $\mathrm{T}$ can support a clearer interpretation of canopy function, productivity, and transpiration efficiency. This inference can support remote sensing of canopy processes using temperature effects

Submitted for review in August 2011 as manuscript number SW 9324; approved for publication by the Soil \& Water Division of ASABE in March 2012. Presented at the 5th National Decennial Irrigation Conference as Paper No. IRR1010030.

The authors are Robert M. Aiken, Associate Professor, Kansas State University, Northwest Research-Extension Center (NWREC), Colby, Kansas; and Norman L. Klocke, ASABE Member, Professor, Kansas State University, Southwest Research-Extension Center (SWREC), Garden City, Kansas. Corresponding author: Robert M. Aiken, Kansas State University, NWREC, 105 Experiment Farm Road, Colby, KS 67701; phone: 785-462-6281; e-mail: raiken@ksu.edu.
(Norman et al., 1995; Bastiaanssen et al., 1998).

In situ measures of $\mathrm{T}$ can support field analysis of plant and environmental effects. Baker and van Bavel (1987) showed that sap flow can be computed as a residual from the energy balance for an insulated heat source, applied to a section of stem (using a radial geometric configuration). Ham et al. (1991) utilized this method with sap flow heat gauges (SFHG) to quantify $\mathrm{T}$ in cotton. Zeggaf et al. (2008) reported that $\mathrm{T}$ in corn (Zea mays $\mathrm{L}$.), calculated from SFHG, corresponded with that derived from a Bowen ratio method; Sauer et al. (2007) reported that soybean (Glycine $\max (\mathrm{L}$.$) Merr.) T, calculated from SFHG, accounted for$ $88 \%$ to $92 \%$ of ET measured by an eddy covariance system for a full, narrow-row, indeterminate soybean canopy on sunny days. The operational utility of SFHG can vary due to stem damage, changing with associated sensor heat transfer characteristics and plant responses to fluctuating environmental conditions. Information about the operational performance of SFHG can guide field applications of this technique.

The combination equation of Penman (1948) provides a thermodynamic basis for analysis of the convective and radiative processes that drive E. Monteith (1965) introduced plant canopy resistance to Penman's equation, enhancing analysis of vegetative canopy effects on evaporative flux. The Penman-Monteith equation (P-M; Monteith, 1973; Allen et al., 1998) provides one of several methods to quantify crop water use, which can guide irrigation scheduling. McArthur (1990), as well as Lascano and van Bavel 
(2007), analyzed a negative bias inherent in the P-M equation (Monteith, 1973) resulting from the assumption of similar thermal and vapor pressure conditions for evaporative source and ambient sink. Lascano et al. (2010) demonstrated that a recursive combination method (RCM), solving for surface temperature as well as evaporative flux, simulated daily ET with root mean squared differences of $0.05 \mathrm{~mm}$ relative to measurements from a field lysimeter with 0.05 $\mathrm{mm}$ accuracy. Incorrect parameterization of canopy resistance $\left(r_{c}\right)$, a transfer coefficient used in both the P-M and the RCM, can propagate substantial error to calculated values of ET (Monteith, 1965; Shuttleworth and Wallace, 1985, Hay and Irmak, 2010; Lascano et al., 2010). Independent calculation of the transpiration component of ET can support the use of energy balance models such as P-M or RCM to evaluate alternative water management practices. Our research objectives were to develop and evaluate a canopy resistance model, to evaluate operational characteristics of SFHG for field corn, and to compare transpiration flux calculated by SFHG with ET calculated by the P-M algorithm.

\section{Method ANd Materials}

Transpiration of a well-watered corn crop was inferred from SFHG measurements collected during flowering and grain fill growth stages. Expected ET was calculated from on-site weather data using the P-M algorithm; canopy resistance $\left(r_{c}\right)$ was assumed to be constant or a non-linear function of absorbed photosynthetically active radiation (APAR) and effective leaf area The $r_{c}$ function was derived from principles of photosynthesis and radiation use. Linear regression was used to evaluate the relationship of $\mathrm{T}$ calculated from SFHG measurements with ET calculated from $\mathrm{P}-\mathrm{M}$, considering alternative assumptions of $r_{c}$.

\section{Crop Culture}

Corn was direct-seeded $\left(71,600\right.$ plants $\left.\mathrm{ha}^{-1}\right)$ during the final week of May in 2004 and in 2006, with no-till management as part of a cropping sequence and irrigation quantity study near Kansas State University's ResearchExtension Center near Garden City, Kansas $\left(37.97^{\circ} \mathrm{N}\right.$, $\left.100.83^{\circ} \mathrm{W}\right)$. The soil was formed on upland plains in calcareous loess that is deep and well-drained. The soil type was a Ulysses silt loam (fine-silty, mixed, mesic Aridic Haplustoll) with an available water capacity of $180 \mathrm{~mm} \mathrm{~m}^{-1}$ between field capacity (34\% volumetric) and permanent wilting (16\% volumetric), $\mathrm{pH}$ of 8.1 , and an organic matter content of $1.5 \%$. Long-term average climatic data for Garden City are annual precipitation of $454 \mathrm{~mm}$, mean temperature of $12^{\circ} \mathrm{C}$, open-pan evaporation (April to September) of $1810 \mathrm{~mm}$, and frost-free period of 170 days. Cultural practices, including hybrid selection, no-till planting techniques, fertilizer applications, and weed control, were not limiting to crop production. Crop was irrigated at semiweekly frequency using sprinklers on a linear-move system to meet evaporative demand with no more than $50 \%$ depletion of available soil water. Experimental treatments were replicated in four blocks (this study was a subset of a larger study, Klocke et al., 2011). Sap flow gauges were installed only on plots $(13.7 \mathrm{~m} \times 28.0 \mathrm{~m})$ receiving full irrigation within each replicate block.

\section{SAP Flow Heat GaUge Instrumentation}

Sap flow heat gauges (SF19, Dynamax, Houston, Tex.) were installed on stems of five plants at the third internode at tasseling developmental stage (tassel visible), following the manufacturer's instructions, on each of four replicate plots. Prior to installation, stem diameter (maximum and minimum) at midpoint of the internode was recorded. Leaf sheaths were removed, and silicone spray lubricant was applied to the stem to ensure adequate gauge contact with the stem. Closed-cell foam insulation and an aluminum reflective shield, sealed with electrical tape, minimized energy exchange with the environment and shielded the ensemble from rainfall and irrigation water. After two weeks, two gauges from replicates 1 and 3 , and three gauges from replicates 2 and 4 were moved to adjacent plants, following identical installation procedures. After a third week, the remaining gauges were moved to adjacent plants. Five weeks after initial installation, the gauges were moved to a third set of plants. Identical procedures were followed in 2006, with the exception that three gauges of each plot were Dynamax and the remaining two gauges were fabricated by the experimentalist following a similar design documented by Bremer and Tarara (1994).

Extension cables (Belden 9450, 24 AWG, shielded) of equal length $(10 \mathrm{~m})$ conducted thermocouple signals from the gauges to a multiplexer (AM416, Campbell Scientific, Logan, Utah) shielded within an insulated enclosure located in the field plot. Extension cables maintained communication between the four multiplexers and a datalogger (23X, Campbell Scientific, Logan, Utah) centrally located among the field plots. Commercial 12-gauge insulated copper wire conducted power to a terminal strip in each enclosure, to which the appropriate leads of the sap flow gauges were connected. A voltage reading of attenuating precision resistors $(5 \mathrm{k} \Omega / 20 \mathrm{k} \Omega, 0.1 \%$ precision) connected to the positive and negative leads of the terminal strip provided a proportionate measure of the power supplied to each set of gauges.

To minimize stem damage from heating during low-flow periods, power was regulated by the datalogger, a relay driver (A6REL-12, Campbell Scientific, Logan, Utah), and a controlled dual adjustable voltage regulator (AVRDC, Dynamax, Houston, Tex.). A reduced voltage (1 V) input was applied to the gauges from 18:00 h through 5:00 h, when expected transpiration flux was less than $200 \mathrm{~W} \mathrm{~m}^{-2}$ $\left(0.3 \mathrm{~mm} \mathrm{~h}^{-1}\right)$. Normal voltage input $(4 \mathrm{~V})$ was applied to the gauges from 9:00 $\mathrm{h}$ through 18:00 $\mathrm{h}$, when transpiration flux was expected to exceed $200 \mathrm{~W} \mathrm{~m}^{-2}\left(0.3 \mathrm{~mm} \mathrm{~h}^{-1}\right)$ and pre-dawn $(5: 00 \mathrm{~h}$ through $6: 00 \mathrm{~h})$ as required to calculate a gauge constant (quantifying heat loss for radial geometry). Thermocouple signals were received at $10 \mathrm{~s}$ intervals and integrated to averages at $12 \mathrm{~min}$ intervals. The system was powered by deep-cycle batteries (L16G, Trojan, Sante Fe Springs, Cal.) recharged by a $1.1 \mathrm{~m}^{2}$ solar panel (SG105, Carizzo Solar Corp.).

Analysis of sap flow followed that of Baker and van Bavel (1987) and Ham and Heilman (1990). Power applied 
via resistance heaters wrapped around the stem $(Q)$ was partitioned into components including stem axial thermal conduction away from the gauge $\left(Q_{v}\right)$, radial loss out the insulated gauge $\left(Q_{r}\right)$, and convective transfer via sap flow $\left(Q_{f}\right)$ :

$$
Q=Q_{v}+Q_{r}+Q_{f}
$$

where all terms have units of watts (W). Sets of thermocouple temperature sensors embedded above and below the resistance heater provide information required to quantify these flow components. At steady state, sap flow was calculated as a residual of the energy balance by:

$$
F=\frac{Q-Q_{v}-Q_{r}}{c_{w}\left(T_{o}-T_{i}\right)}
$$

where $F$ is transpiration flow $\left(\mathrm{kg} \mathrm{s}^{-1}\right) ; T_{o}$ and $T_{i}$ are apparent temperatures $(\mathrm{K})$ of the transpiration stream above and below the heat source, respectively; $c_{w}$ is the specific heat of water $\left(\mathrm{J} \mathrm{kg}^{-1} \mathrm{~K}^{-1}\right)$; and the other terms are previously defined. Transpiration flow was scaled from plant to land area basis using stand density (here 7.4 plants $\mathrm{m}^{-2}$ ) and converted from units of mass flux $\left(\mathrm{kg} \mathrm{s}^{-1}\right)$ to energy flux $\left(\mathrm{W} \mathrm{m}{ }^{-2}\right)$ by multiplying $F$ by the latent heat of vaporization and by stand density.

Solution of equation 2 required knowledge of a gauge constant related to conductive heat transport, determined from pre-dawn observations when $Q_{f} \sim 0$. An undiagnosed ground fault confounded this analysis. Bias in the signal associated with the gauge constant was identified and removed for each installation of each gauge (see Appendix). Gauge accuracy was expected to be largest when sap temperature increases were approximately $2^{\circ} \mathrm{C}$ (van Bavel et al., 2000; Bremer and Tarrara, 1994). The manufacturer recommended data filters, corresponding to low and high sap flow rates, where assumptions for gauge readings were invalid. The criteria for low flow were $Q_{f}<0.2 Q$ and $\left(T_{o}-\right.$ $\left.T_{i}\right)<0.75^{\circ} \mathrm{C}$; the criterion for high flow was $Q_{f}>0.8 Q$. Observations meeting low-flow or high-flow criteria were excluded from further analysis.

\section{WEATHER INSTRUMENTATION AND P-M CALCULATION}

Weather instrumentation included a pyranometer (Li200, Li-Cor, Lincoln, Neb.) at $2 \mathrm{~m}$ height for global solar irradiance, a net radiometer $\left(\mathrm{Q}^{*}\right.$ 7.1, REBS, Bellevue, Wash.) at $2 \mathrm{~m}$ height, a temperature and humidity sensor (HMP45C, Vaisala, Inc. Woburn, Mass.) at $2 \mathrm{~m}$ height, and a wind velocity sensor (014A, Met-One, Grants Pass, Ore.) at $3 \mathrm{~m}$ height. Soil heat flux was measured by heat flow plates (HFT3.1, REBS, Bellevue, Wash.) at $0.1 \mathrm{~m}$ soil depth and adjusted for transient heat storage effects above the heat flow plates. Sensor signals were recorded by a datalogger (21X, Campbell Scientific, Logan, Utah) operating at $10 \mathrm{~s}$ frequency, and values were integrated over $1 \mathrm{~h}$ intervals. Instrumentation was installed within one of the well-watered plots included in this study.

Expected latent heat, associated with $\mathrm{ET}\left(\lambda \mathrm{ET}_{\mathrm{PM}}, \mathrm{W} \mathrm{m} \mathrm{m}^{-2}\right)$, was calculated from the soil and weather instrumentation by the Penman-Monteith equation (Monteith, 1973, Allen et al., 1998):

$$
\lambda \mathrm{ET}_{\mathrm{PM}}=\frac{\Delta\left(R_{n}-G\right)+\rho C_{p}(v p d) / r_{a}}{\Delta+\gamma\left(1+r_{c} / r_{a}\right)}
$$

where $\Delta$ is the slope of the saturated vapor pressure function of temperature, evaluated at ambient temperature $(\mathrm{kPa}$ $\left.{ }^{\circ} \mathrm{C}^{-1}\right), R_{n}$ is net radiation $\left(\mathrm{W} \mathrm{m}^{-2}\right), G$ is soil heat flux $\left(\mathrm{W} \mathrm{m}^{-2}\right)$, $\rho C_{p}$ is volumetric heat capacity of air $\left(\mathrm{J} \mathrm{K}^{-1} \mathrm{~m}^{-3}\right), r_{a}$ is aerodynamic resistance between canopy source height and reference level $\left(\mathrm{s} \mathrm{m}^{-1}\right), \gamma$ is the psychrometric constant $(\mathrm{kPa}$ $\left.{ }^{\circ} \mathrm{C}^{-1}\right)$, and $r_{c}$ is bulk stomatal resistance of the canopy $\left(\mathrm{s} \mathrm{m}^{-1}\right)$. Aerodynamic resistance was calculated from the wind profile law for neutral conditions (no adjustment for stability conditions, Allen et al., 1998), with measurement height of $2.0 \mathrm{~m}$, displacement height of $0.95 \mathrm{~m}$, and roughness length of $0.05 \mathrm{~m}$. Bulk canopy resistance $\left(r_{c}\right)$ is a boundary condition to equation 3 and was calculated by scaling $r_{s}$ or its inverse, stomatal conductance $\left(g_{s}, \mathrm{~m} \mathrm{~s}^{-1}\right)$, at individual leaf scale, up to canopy scale considering effective leaf area in$\operatorname{dex}\left(\mathrm{LAI}_{\mathrm{eff}}, \mathrm{m}^{2} \mathrm{~m}^{-2}\right)$ as follows (Farahani and DeCoursey, 2000):

$$
r_{c}=\frac{r_{s}}{2\left(\mathrm{LAI}_{\mathrm{eff}}\right)}=\frac{1}{g_{s} \cdot 2\left(\mathrm{LAI}_{\mathrm{eff}}\right)}
$$

where the multiplier of 2 applies to amphistomotous leaves (upper and lower leaf surfaces), and $\mathrm{LAI}_{\text {eff }}$ was calculated as half of LAI when LAI exceeded $3 \mathrm{~m}^{2} \mathrm{~m}^{-2}$ (Allen et al., 1998). Stomatal resistance was specified as a constant (130, 250 , or $425 \mathrm{~s} \mathrm{~m}^{-1}$ ) or calculated as a function of absorbed radiation (described below). The range of values for $r_{s}$ was selected to (1) represent well watered conditions (Allen et al., 1998, reported an $r_{s}$ value of approximately $100 \mathrm{~s} \mathrm{~m}^{-1}$ for a well-watered leaf; Turner and Begg, 1973, reported $r_{s}$ ranging from 100 to $500 \mathrm{~s} \mathrm{~m}^{-1}$ for well-watered corn) and (2) demonstrate the sensitivity of $\lambda \mathrm{ET}_{\mathrm{PM}}$ to $r_{c}$. Leaf area index was determined by a non-destructive light transmission technique (LAI-2000, Li-Cor, Lincoln, Neb.). Energy balance components calculated from hourly weather conditions were compared with the hourly integration of sap flow quantified at 12 min intervals.

\section{Canopy Conductance Model}

Stomatal conductance can be deduced from knowledge of absorbed radiation, enzyme kinetics, and the hypothesis that leaf stomata adjust to prevailing light conditions to maintain optimal enzyme kinetics (Cowan and Farquhar, 1977). Krall and Edwards (1992) showed that 10 to 12 electrons from photosystem II (PSII) are typically required, in corn, for each $\mathrm{CO}_{2}$ molecule that is converted into hexose. Earl and Davis (2003) demonstrated that this relationship could account for effects of drought stress on leaf and crop radiation use efficiency of corn. Accordingly, assimilation of $\mathrm{CO}_{2}\left(A^{*}\right)$ can be calculated from:

$$
A^{*}=\mathrm{APAR} \cdot \phi_{\mathrm{PSII}}\left(\frac{\phi_{\mathrm{CO} 2}}{\phi_{\mathrm{PSII}}}\right)
$$

where $A *$ is the gross assimilation of $\mathrm{CO}_{2}\left(\mu \mathrm{mol} \mathrm{CO}_{2} \mathrm{~m}^{-2} \mathrm{~s}^{-1}\right)$, APAR is the absorbed photosynthetically active radiation ( $\mu \mathrm{mol}$ photons $\mathrm{m}^{-2} \mathrm{~s}^{-1}$ ), $\phi_{\text {PSII }}$ is the quantum yield of photo- 
system II ( $\mu \mathrm{mol}$ electrons $\mathrm{m}^{-2} \mathrm{~s}^{-1} \mu \mathrm{mol}^{-1}$ absorbed photons utilized by PSII $\mathrm{m}^{2} \mathrm{~s}^{-1}$ ), and $\phi_{\mathrm{CO} 2}$ is the quantum yield for $\mathrm{CO}_{2}$ assimilation ( $\mu \mathrm{mol} \mathrm{CO} \mathrm{m}^{-2} \mathrm{~s}^{-1} \mu \mathrm{mol}^{-1}$ photons APAR $\mathrm{m}^{2} \mathrm{~s}^{-1}$ ). Absorbed PAR (APAR) can be calculated from solar irradiance (assuming that $f_{\mathrm{PAR}}$, the fraction of sunlight that is photosynthetically active, is 0.47 ; Meek et al., 1984; Jacovides et al., 2003) and knowledge of canopy visible reflectance $(\alpha$, here assumed to be 0.1$)$ and transmittance $(\tau$, here assumed to be 0$)$ :

$$
\mathrm{APAR}=f_{\mathrm{PAR}} \cdot(1-\alpha-\tau) \cdot R_{S}
$$

The quantum yield of photosystem II ( $\left.\phi_{\text {PSII }}\right)$ can be calculated from Von Caemmerer and Furbank (1999, p. 182). The ratio $\phi_{\mathrm{CO} 2} / \phi_{\text {PSII }}$ was assumed to be 12 (Krall and Edwards, 1992; Earl and Davis, 2003). Gross assimilation can also be calculated from Fick's law, describing diffusive transport of $\mathrm{CO}_{2}$ from air in the well-mixed canopy layer $\left(C_{a}, \mu \mathrm{mol} \mathrm{m}{ }^{-3}\right)$ to leaf sub-stomatal cavities $\left(C_{i}, \mu \mathrm{mol} \mathrm{m}{ }^{-3}\right)$ :

$$
A^{*}=g_{s}\left(C_{a}-C_{i}\right)
$$

Stomatal conductance can be derived from equations 5 , 6 , and 7 by substituting terms for $\mathrm{A}^{*}$ and solving for $g_{s}$ :

$$
g_{s}=\frac{\phi_{\mathrm{PSII}} \cdot \mathrm{APAR}}{\left(\frac{\phi_{\mathrm{PSII}}}{\phi_{\mathrm{CO} 2}}\right) \cdot C_{a}\left(1-\frac{C_{i}}{C_{a}}\right)}
$$

where all terms are as previously defined. Bunce (2005) reported that corn leaves maintained a $C_{i} / C_{a}$ ratio of 0.58 . Stomatal resistance is the inverse of stomatal conductance and can be scaled to canopy resistance by equation 4 . Thus, equations 4 and 8 provide a means of quantifying $r_{c}$ as a function of APAR and $\mathrm{LAI}_{\text {eff }}$ A second-order linear relationship between $r_{c}$ and APAR (100 to $2400 \mu \mathrm{mol} \mathrm{m} \mathrm{m}^{-2} \mathrm{~s}^{-1}, 100$ unit increments) was fit to the solution of equations 4 and 8 with the specified boundary conditions. This relationship:

$$
\begin{gathered}
r_{c}=0.001094+8.87 \mathrm{E}-6(\mathrm{APAR})-2.29 \mathrm{E}-9\left(\mathrm{APAR}^{2}\right) \\
\left(\mathrm{R}^{2}=0.982\right)
\end{gathered}
$$

is shown in figure 1 and was used in subsequent implementation of the P-M equation with variable $r_{c}$.

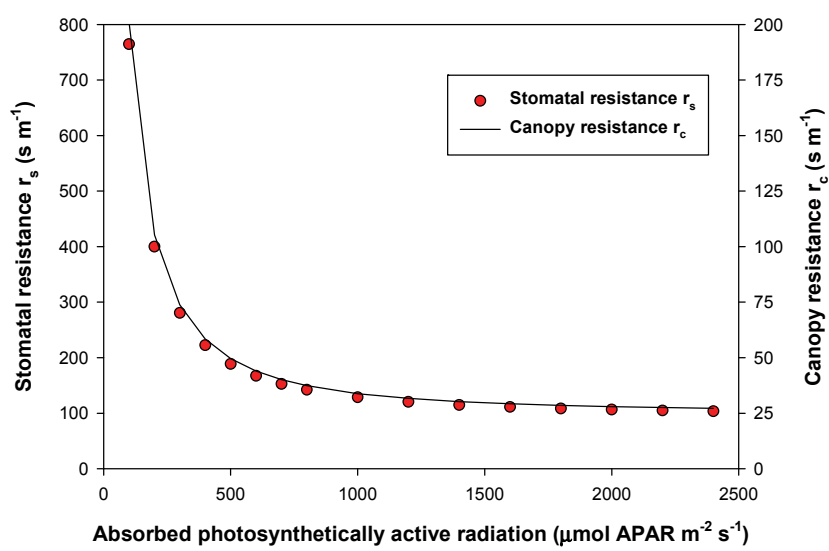

Figure 1. Stomatal resistance $\left(r_{s}\right)$ calculated from equation 8 as the inverse of stomatal conductance $\left(g_{s}\right)$ in relation to absorbed photosynthetic radiation (APAR). Complementary calculation of canopy resistance $\left(r_{c}\right)$ was calculated from equation 4 and LAI of $3.8 \mathrm{~m}^{2} \mathrm{~m}^{-2}$.

\section{RESULTS}

\section{Operational Performance}

Gauge installation and operation led to disruption of plant processes, affecting stem integrity and altered yield formation. These effects were detected by loss of gauge function, indicated by substantially reduced transpiration rates and, at harvest, by reduced grain yield. Typically, loss of gauge function would be indicated by reduced apparent transpiration flow ( $F$, calculated from eq. 2 ), followed by virtual cessation of sap flow ( $Q_{f}$, calculated from eq. 1) within two to three days. Half of the gauges were not operating approximately one to two weeks following installation. Gauge function declined more rapidly for the gauges installed during mid-grain fill (DOY 239 and 247) relative to the gauges installed during early grain fill (DOY 210 and 226). Details are provided by Aiken and Klocke (2010). Measurements from gauges indicating an initial loss of function were excluded from further analysis of sap flow.

\section{Transpiration ANALYSIS}

Crop canopy resistance $\left(r_{c}\right)$ is a boundary condition to $\mathrm{P}$ $\mathrm{M}$, which must be specified by the user. Reasonable assumptions about $r_{c}$ include constant $r_{s}$, reflecting open stomata for a well-watered crop (Allen al., 1998), or variable $r_{s}$, representing adjustment to prevailing light conditions (Turner and Begg, 1973) to maintain optimal enzyme kinetics (Cowan and Farquhar, 1977). Effects of these alternative assumptions on $\lambda E T_{\mathrm{PM}}$ are shown in figure 2 for the weather conditions observed on DOY 236, a representative clear day with moderate wind ( 0.3 to $\left.2.1 \mathrm{~m} \mathrm{~s}^{-1}\right)$ and vapor pressure deficit $(0.1$ to $3.4 \mathrm{kPa})$. Here, $r_{s}$ was assumed constant $\left(130,250\right.$ or $425 \mathrm{~s} \mathrm{~m}^{-1}$, corresponding to $r_{c}$ values of 34,66 , or $112 \mathrm{~s} \mathrm{~m}^{-1}$ ) selected to represent a range of expected values (Turner and Begg, 1973) or variable, in proportion to APAR and LAI (fig. 1). Canopy resistance was calculated from equation 4 with LAI observed among the experimental plots $\left(3.8 \mathrm{~m}^{2} \mathrm{~m}^{-2}\right)$. Calculated mid-day $\lambda \mathrm{ET}_{\mathrm{PM}}$ values ranged from $480 \mathrm{~W} \mathrm{~m}^{-2}\left(r_{c}=112 \mathrm{~s} \mathrm{~m}^{-1}\right)$ to $590 \mathrm{~W} \mathrm{~m}^{-2}$

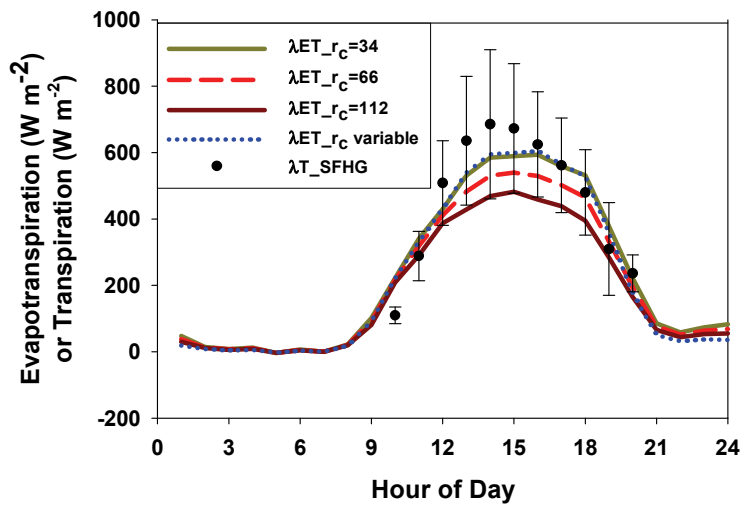

Figure 2. Evapotranspiration, as calculated by the Penman-Monteith equation, for weather conditions observed on DOY 236 using four differing assumptions for stomatal resistance $\left(r_{s}\right)$. Stomatal resistance was held constant $\left(130,250\right.$, or $425 \mathrm{~s} \mathrm{~m}^{-1}$, corresponding to canopy resistance $\left(r_{c}\right)$ of 34,66 , or $112 \mathrm{~s} \mathrm{~m}^{-1}$ ), or assumed to vary in proportion to absorbed radiation (eqs. 4 and 8). Transpiration values, calculated from sap flow heat gauges, are for 10:00 h through $20: 00 \mathrm{~h} ; 90 \%$ confidence intervals are constructed using standard error from mean values from each of four field plots. 


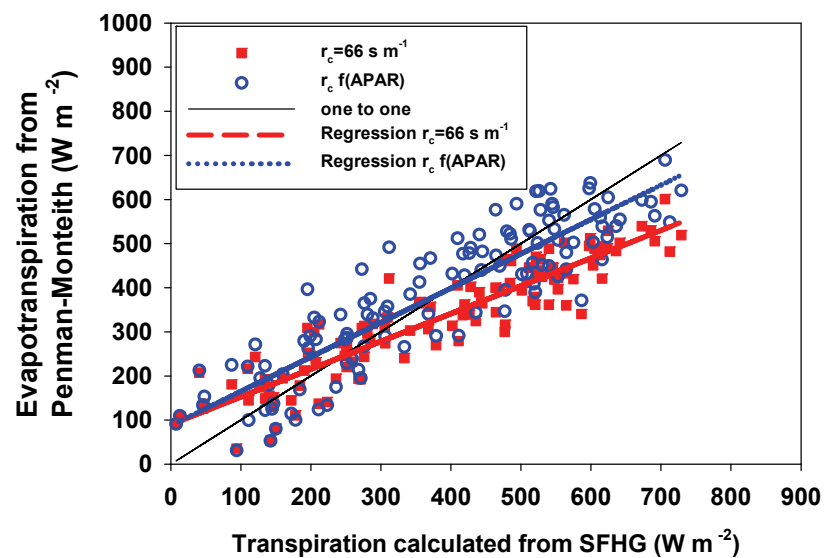

Figure 3. Evapotranspiration, calculated from hourly weather data using the Penman-Monteith equation and corresponding transpiration, calculated from sap flow heat gauges. Data were collected from DOY 225-238 during mid-grain fill for a well-watered crop. Evapotranspiration was calculated from the Penman-Monteith equation assuming that canopy resistance $\left(r_{c}\right)$ was either constant $\left(66 \mathrm{~s} \mathrm{~m}^{-1}\right)$ or varied in proportion to absorbed radiation.

$\left(r_{c}=34 \mathrm{~s} \mathrm{~m}^{-1}\right)$, indicating the influence of $r_{c}$ on calculated transpiration. Evapotranspiration calculated with variable $r_{c}$, (function of APAR and LAI) was similar to that calculated with constant $r_{c}=34 \mathrm{~s} \mathrm{~m}^{-1}$ for most of the sunlit period. Transpiration calculated from SFHG measurements $\left(\lambda \mathrm{T}_{\mathrm{SFHG}}\right)$ was $49 \%$ of $\lambda \mathrm{ET}_{\mathrm{PM}}$ calculated with constant $r_{c}=$ $34 \mathrm{~s} \mathrm{~m}^{-1}$ at mid-morning $(10: 00 \mathrm{~h})$ but exceeded $\lambda \mathrm{ET}_{\mathrm{PM}}$ by up to $17 \%$ from $12: 00 \mathrm{~h}$ through $16: 00 \mathrm{~h}$. Confidence intervals $(90 \%)$ constructed about $\lambda \mathrm{T}_{\mathrm{SFHG}}$ values contained $\lambda \mathrm{ET}_{\mathrm{PM}}$ values for most conditions after 10:00 $\mathrm{h}$.

The predictive accuracy of the P-M equation was evaluated in relation to sap flow, as calculated from two to five operational gauges in each of four replicated field plots for well-watered corn during the mid-grain fill period (DOY 225 to 238). Evapotranspiration was calculated from hourly weather data with the assumption of either constant $r_{c}\left(r_{c}=\right.$ $66 \mathrm{~s} \mathrm{~m}^{-1}$, an intermediate value) or variable $r_{c}$ (proportional to APAR). Calculated $\lambda \mathrm{ET}_{\mathrm{PM}}$ was regressed on corresponding hourly integrals of overall mean values of SFHG values $\left(\lambda \mathrm{T}_{\mathrm{SFHG}}\right)$ (fig. 3). The coefficient of determination $\left(\mathrm{R}^{2}\right)$ and standard error (SE) are specified for each regression equation:

$$
\begin{aligned}
& \text { With } r_{c}=34 \mathrm{~s} \mathrm{~m}^{-1}: \\
& \lambda \mathrm{ET}_{\mathrm{PM}}=117.5+0.700\left(\lambda \mathrm{T}_{\mathrm{SFHG}}\right) \\
& \left(\mathrm{R}^{2}=0.795, \mathrm{SE}=66.6\right) \\
& \text { With } r_{c}=66 \mathrm{~s} \mathrm{~m}^{-1}: \\
& \lambda \mathrm{ET}_{\mathrm{PM}}=89.4+0.629\left(\lambda \mathrm{T}_{\mathrm{SFHG}}\right) \\
& \quad\left(\mathrm{R}^{2}=0.848, \mathrm{SE}=50.0\right) \\
& \text { With } r_{c}=112 \mathrm{~s} \mathrm{~m}^{-1}: \\
& \lambda \mathrm{ET}_{\mathrm{PM}}=66.2+0.548\left(\lambda \mathrm{T}_{\mathrm{SFHG}}\right) \\
& \quad\left(\mathrm{R}^{2}=0.838, \mathrm{SE}=45.1\right) \\
& \text { With } r_{c}=f(\mathrm{APAR}): \\
& \lambda \mathrm{ET}_{\mathrm{PM}}=87.3+0.779\left(\lambda \mathrm{T}_{\mathrm{SFHG}}\right) \\
& \left(\mathrm{R}^{2}=0.793, \mathrm{SE}=74.6\right)
\end{aligned}
$$

Predictive bias was indicated by the intercept deviating from zero and the slope deviating from unity. These results indicate offsetting biases in slope and intercept for $\lambda \mathrm{ET}_{\mathrm{PM}}$ relative to $\lambda \mathrm{T}_{\mathrm{SFHG}}$ for all regression equations. These biases are consistent, with the pattern of small $\lambda \mathrm{T}_{\mathrm{SFHG}}$ relative to $\lambda \mathrm{ET}_{\mathrm{PM}}$ at $10: 00 \mathrm{~h}$ and large $\lambda \mathrm{T}_{\mathrm{SFHG}}$ relative to $\lambda \mathrm{ET}_{\mathrm{PM}}$ at mid-day (fig. 2). Greater precision was obtained with the assumption of constant $r_{c}=66 \mathrm{~s} \mathrm{~m}^{-1}$. However, less apparent bias resulted from the assumption of variable $r_{c}$.

\section{DisCuSSION}

The canopy resistance model presented here, derived from principles of photosynthesis and radiation use, permits direct calculation of $r_{c}$ from radiation absorbed by the canopy. This relationship is supported by micrometeorological evidence that relates assimilation and transpiration to absorbed radiation (Rochette et al., 1996). Tolk et al. (1996) analyzed transpiration measured by SFHG and by lysimetry, deriving a relationship between plant resistance to transpiration and radiance values that is similar in form and scale to that shown in figure 1 . The magnitude of $r_{c}$ calculated by equations 4 and 8 , for corn at $1000 \mathrm{~W} \mathrm{~m}^{-2}$ solar irradiance $\left(1946 \mathrm{~mol}\right.$ APAR m $\left.\mathrm{m}^{-2} \mathrm{~s}^{-1} ; r_{c}=38 \mathrm{~s} \mathrm{~m}^{-1}\right)$ is consistent with that given by Tolk et al. (1996) for irrigated corn $\left(r_{c}=37 \mathrm{~s} \mathrm{~m}^{-1}\right)$, used by Hay and Irmak (2010) for irrigated grass $\left(r_{c}=40 \mathrm{~s} \mathrm{~m}^{-1}\right)$, and derived by Lascano et al. (2010) for irrigated alfalfa $\left(r_{c}=32.1 \mathrm{~s} \mathrm{~m}^{-1}\right)$. Considering the potential utility of this independent $r_{c}$ model, formulated in relation to radiation use, further field evaluation is warranted.

The P-M equation is one of many forms of a surface energy balance equation that can be applied to water management. The recursive combination method (RCM) evaluated by Lascano and van Bavel (2007) resulted in greater $\mathrm{ET}_{p}$ (reference $\mathrm{ET}$ ) and $\mathrm{ET}_{a}$ (actual ET) relative to their implementation of the explicit combination method (ECM) of Penman (1948). However, Hay and Irmak (2010) reported that ECM and RCM both gave similar agreement to ET calculated from Bowen ratio energy balance (BREB) measurements over irrigated grass. Other energy balance equation models explicitly partition ET into canopy and substrate sources (Shuttleworth and Wallace, 1985), with applications to remote sensing (Norman et al, 1995; Bastiaanssen et al., 1998). Each formulation of these energy balance models of crop ET requires a transfer coefficient related to the evaporative source (i.e., $r_{c}$ ), and uncertainty in parameterization of $r_{c}$ introduces substantial uncertainty into the solution for $\mathrm{ET}_{a}$ (Monteith, 1973; Shuttleworth and Wallace, 1985; Lascano et al., 2010).

Several investigators employed SFHG in analysis of canopy and substrate contributions to ET. Chabot et al. (2005) compared T of sugarcane from SFHG with that of the P-M equation and attributed a $35 \%$ positive bias to uncertainty in scaling sap flow from plant to whole canopy based on plant density. Ham et al. (1990) compared T of cotton using SFHG with ET determined by a BREB method; they scaled sap flow on a relative leaf area basis and on a plant density basis. Independent measure of soil $\mathrm{E}$ by micro-lysimeters indicated superior agreement with BREB 
when scaling on a relative leaf area basis; they reported a $\mathrm{T} / \mathrm{ET}$ ratio of 0.57 for an incomplete crop canopy. Zeggaf et al. (2008) found that $\mathrm{T}$ of corn measured by SFHG was $86 \%$ of that measured by a BREB method; data reported by the authors indicated that the canopy absorbed $43 \%$ of net radiation and that the ratio of $\mathrm{T} / \mathrm{ET}$ was 0.53 , based on SFHG and lysimeter measurements. Sauer et al. (2007) reported that $90 \%$ of solar radiation and net radiation was absorbed by a narrow-row, indeterminate soybean canopy and that over $80 \%$ of this energy resulted in ET; the fraction of E/ET ranged from 0.08 to 0.12 . In the present study, the apparent reduction of bias in $\mathrm{ET}_{\mathrm{PM}}$ with the variable $r_{c}$ model, relative to that calculated with the constant $r_{c}$ model, suggests that SFHG measurements can contribute to understanding of soil and plant sources of ET.

\section{CONCLUSION}

Limiting gauge operation on a single plant to a maximum of one week should reduce impacts on stem biological function. Uncertainty in stomatal behavior was similar in magnitude to potential bias in transpiration calculated from SFHG, relative to evapotranspiration calculated by PM. Sap flow gauges provided information useful for evaluating a canopy resistance model, derived from principles of radiation use, which reduced apparent bias in $\mathrm{ET}_{\mathrm{PM}}$ relative to $\lambda T_{\mathrm{SFHG}}$.

\section{ACKNOWLEDGEMENTS}

This research was funded by the Kansas Agricultural Experiment Station and the Ogallala Aquifer Program, a consortium among the USDA-ARS, Kansas State University, Texas AgriLife Research, Texas AgriLife Extension Service, Texas Tech University, and West Texas A\&M University. Dennis Tomsicek provided invaluable technical support during operation of the sap flow gauges.

\section{REFERENCES}

Aiken, R. M., and N. L. Klocke. 2010. Operational characteristics of sap flow heat gauges to quantify transpiration flux in corn. In Proc. 5th National Decennial Irrigation Conf., Paper No. IRR1010030. St. Joseph, Mich.: ASABE.

Allen, R. G., L. S. Pereira, D. Raes, and M. Smith. 1998. Crop evapotranspiration: Guidelines for computing crop water requirements. Irrigation and Drainage Paper 56. Rome, Italy: United Nations FAO.

Baker, J. M., and C. H. M. van Bavel. 1987. Measurement of mass flow of water in stems of herbaceous plants. Plant, Cell, and Environ. 10(9): 777-782.

Bastiaanssen, W. G. M., M. Menenti, R. A. Feddes, and A. A. M. Holtslag. 1998. A remote sensing surface energy balance algorithm for land (SEBAL): 1. Formulation. J. Hydrol. 212213: 198-212.

Bremer, D., And J. Tarara. 1994. Sap Flow Gauge Manual. Manhattan, Kans.: Micromet Publications.

Bunce, J. A. 2005. What is the usual internal carbon dioxide concentration in $\mathrm{C}_{4}$ species under midday field conditions? Photosynthetica 43(4): 603-608.

Chabot, R. S. Bouarfa, D. Zimmer, C. Chaumont, and S. Moreau. 2005. Evaluation of the sap flow determined with a heat balance method to measure the transpiration of a sugarcane canopy. Agric. Water Mgmt. 75(1): 10-24.

Cowan, I. R., and G. D. Farquhar. 1977. Stomatal function in relation to leaf metabolism and environment. In Integration of Activity in the High Plant, 471-505. D. H. Jennings, ed. Society for Experimental Biology Symposium No. 31. Cambridge, U.K.: Cambridge University Press.

Earl, H. J., and R. F. Davis. 2003. Effect of drought stress on leaf and whole-canopy radiation use efficiency and yield of maize. Agron. J. 95(3): 688-696.

Farahani, H. J., and D. G. DeCoursey. 2000. Potential evaporation and transpiration processes in the soil-residue-canopy system. In Root Zone Water Quality Model, 51-80. L. R. Ahuja, K. W. Rojas, J. D. Hanson, M. J. Shaffer, and L. Ma, eds. Highlands Ranch, Colo.: Water Resources Publications.

Ham, J. M., and J. L. Heilman. 1990. Dynamics of a heat balance stem flow gauge during high flow. Agron. J. 82(1): 147-152.

Ham, J. M., J. L. Heilman, and R. J. Lascano. 1990. Determination of soil water evaporation and transpiration from energy balance and stem flow measurements. Agric. Forest Meteorol. 52(3-4): 287-301.

Ham, J. M., J. L. Heilman, and R. J. Lascano. 1991. Soil and canopy energy balances of a row crop at partial cover. Agron. J. 83(4): 744-753.

Hay, C. H., and S. Irmak. 2010. Recursive and explicit combination-based energy balance equations for calculating reference evapotranspiration in relation to Bowen ratio measurements. Trans. ASABE 53(6): 1799-1810.

Jacovides, C. P., F. S. Tymvios, D. N. Asimakopoulos, K. M. Theofilou, and S. Pashiardes. 2003. Global photosynthetically active radiation and its relationship with global solar radiation in the eastern Mediterranean basin. Theor. Appl. Climatol. 74(3-4): 227-233.

Klocke, N. L., R. S. Currie, D. J. Tomsicek, and J. Koehn. 2011. Corn yield response to deficit irrigation. Trans. ASABE 54(3): 931-940.

Krall, J. P., and G. E. Edwards. 1992. Relationship between photosystem II activity and $\mathrm{CO}_{2}$ fixation in leaves. Physiol. Plantarum 86(1): 180-187.

Lascano, R. J., and C. H. M. van Bavel. 2007. Explicit and recursive calculation of potential and actual evapotranspiration. Agron. J. 99(2): 585-590.

Lascano, R. J., R. L. Baumhardt, S. K. Hicks, and J. L. Heilman. 1994. Soil and plant water evaporation from strip-tilled cotton: Measurement and simulation. Agron. J. 86(6): 987-994.

Lascano, R. J., C. H. M. van Bavel, and S. R. Evett. 2010. A field test of recursive calculation of crop evapotranspiration. Trans. ASABE 53(4): 1117-1126.

McArthur, A. J. 1990. An accurate solution to the Penman equation. Agric. Forest Meteorol. 51(1): 87-92.

Meek, D. W., J. L. Hatfield, T. A. Howell, S. B. Idso, and R. J. Reginato. 1984. A generalized relationship between photosynthetically active radiation and solar radiation. Agron. J. 76(6): 939-945.

Monteith, J. L. 1965. Evaporation and environment. In The State and Movement of Water in Living Organisms, 205-234. New York, N.Y.: Academic Press.

Monteith, J. L. 1973. Principles of Environmental Physics. London, U.K.: Edward Arnold.

Norman, J. M., W. P. Kustas, and K. S. Humes. 1995. Source approach for estimating soil and vegetation energy fluxes in observations of directional radiometric surface temperature. Agric. Forest Meteorol. 77(3-4): 263-293.

Penman, H. L. 1948. Natural evaporation from open water, bare soil, and grass. Proc. Royal Soc. A 193(1032): 120-145.

Rochette, P., R. L. Desjardins, E. Pattey, and R. Lessard. 1996. 
Instantaneous measurements of radiation and water use efficiencies of a maize crop. Agron. J. 88(4): 627-635.

Sauer, T. J., J. W. Singer, J. H. Prueger, T. M. DeSutter, and J. L. Hatfield. 2007. Radiation balance and evaporation partitioning in a narrow-row soybean canopy. Agric. Forest Meteorol. 145(3-4): 206-214.

Shuttleworth, W. J., and J. S. Wallace. 1985. Evaporation from sparse crops: An energy combination theory. Qtly. J. Royal Meteorol. Soc. 111(469): 839-855.

Tolk, J. A., T. A. Howell, J. L. Steiner, and D. R. Krieg. 1996. Corn canopy resistance determined from whole plant transpiration. In Evapotranspiration and Irrigation Scheduling: Proc. Intl. Conf., 347-351. C. R. Camp, E. J. Sadler, and R. E. Yoder, eds. St. Joseph, Mich.: ASABE.

Turner, N. C., and J. E. Begg. 1973. Stomatal behavior and water status of maize, sorghum, and tobacco under field conditions. Plant Physiol. 51(1): 31-36.

Van Bavel, M. G., C. H. M. van Bavel, V. Woodie, D. Perry, and S. Thanoon. 2000. Flow32: Windows-based sap flow monitoring system. Installation and operation manual. Houston, Tex.: Dynamax, Inc.

Von Caemmerer, S., and R. T. Furbank. 1999. Modeling $\mathrm{C}_{4}$ photosynthesis. In $C_{4}$ Plant Biology, 173-211. R. F. Sage and R. K. Monson, eds. San Diego, Cal.: Academic Press.

Zeggaf. A. T., S. Takeuchi, H. Dehghanisanij, H. Anyoji, and T. Yano. 2008. A Bowen ratio technique for partitioning energy fluxes between maize transpiration and soil surface evaporation. Agron. J. 100(4): 988-996.

\section{APPENDIX}

The pre-dawn signal from the SFHG thermocouples (ah signal; Van Bavel et al., 2000, p. 29) used to calculate the $Q_{v}$ and $\left(T_{o}-T_{i}\right)$ terms of equation 2 exhibited unusually large values. The behavior of this signal, when voltage was changed, suggested an undiagnosed ground fault. This affected computation of the gauge constant and subsequent calculations. The procedure developed to quantify and correct for apparent systematic bias in $a h$ signal follows:

Step 1. Calculate the actual mean difference in thermocouple signals used in $Q_{v}$ calculation $(b h-a h)$ for the duration of each installation period (12:00 midnight to 4:45 a.m.; the installation period is the time interval from initial installation through termination of gauge operation due to removal or diagnosis of gauge-stem defects, as described in the text).

Step 2. Calculate the expected mean difference in thermocouple signals used in $Q_{v}$ calculations $\left(b h-a h_{c}\right)$ from gauge energy balance components.

$$
\overline{b h-a h_{c}}=\left(\frac{\Delta x \cdot 0.040}{K_{s t} \cdot A_{s t}}\right) \sum_{i=1}^{n}\left(Q_{i}-Q r_{i}\right) / n
$$

where $\Delta x$ is the distance $(\mathrm{m})$ between thermocouple junctions above $(a h)$ and below $(b h)$ the radial heat source, $K_{s t}$ is thermal conductivity of the stem $\left(\mathrm{W} \mathrm{m}^{-1} \mathrm{~K}^{-1}\right)$, and $A_{s t}$ is the stem cross-sectional area $\left(\mathrm{m}^{2}\right)$.

Step 3. Calculate the difference between the expected and observed differences in thermocouple signals used in $Q_{v}$ calculations:

$$
\text { correction }=\left(\overline{b h-a h_{c}}\right)-(\overline{b h-a h})
$$

Step 4. Apply correction to the $a h$ values, and use the corrected values in subsequent calculations for the respective installation period:

$$
a h_{c}=a h-\text { correction }
$$

This bias detection was calculated for each installation of each gauge. 